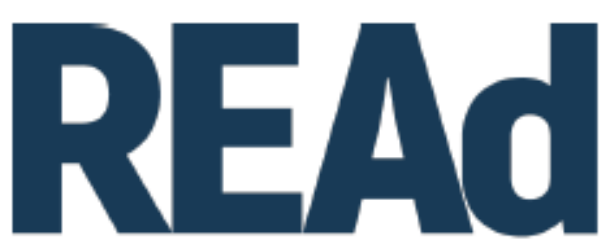

Revista Eletrônica de Administração

\title{
LOW EFFICIENCY IN THE USE OF RESEARCH AND DEVELOPMENT RESOURCES IN BRAZILIAN PUBLIC RESEARCH ORGANIZATIONS: CAUSAL CHAINS ANALYSIS ${ }^{1}$
}

\author{
Fernanda Stringassi de Oliveira ${ }^{2}$ \\ Maria Beatriz Machado Bonacelli ${ }^{3}$
}

http://dx.doi.org/10.1590/1413-2311.257.94205

\begin{abstract}
Open Innovation paradigm brought additional challenges to the already complex Brazilian ST\&I scenario of scarce resources and ineffective public policies. The Public Research Organizations (PROs) face obstacles regarding the limitation imposed by their public nature, complex laws and regulations, inadequate technological and organizational structure, and lack of strategy and priority. Besides that, to improve their results and catch up the competitiveness, Research \& Development (R\&D) projects must be transdisciplinary and collaborative, which usually require a high volume of budget, large teams, and organizational structure for Research Management and Administration (RMA). The low efficiency in the use of physical, financial and human resources are hampering PROs to overcome the financial crisis and backwardness of the national ST\&I results. This study aimed to make a deep analysis of this macro problem in the R\&D Manager perspective as a social actor, based in the Situational Strategic Planning method. The results evidenced the vastness of the problem and supported the comprehension of the social game in place and the work fronts where the actor could tackle the problem. The main conclusion is that PROs must take into account the capacity building in RMA to leverage results and influence positively the ST\&I policy arena.

\footnotetext{
${ }^{1}$ Recebido em 2/7/2019, aceito em 16/9/2019.

${ }^{2}$ Universidade Estadual de Campinas - Instituto de Geociências - Programa de Pós-Graduação em Política Científica e Tecnológica; Embrapa Informática Agropecuária; Campinas - SP (Brasil); http://orcid.org/00000002-6569-3480; fernanda.oliveira@embrapa.br

${ }_{3}$ Universidade Estadual de Campinas - Instituto de Geociências - Departamento de Política Científica e Tecnológica; Campinas - SP (Brasil); http://orcid.org/0000-0003-0795-7684; bia@ige.unicamp.br
} 
Keywords: Research administration. Research projects management. Public research institutions.Public policies.Situational strategy planning.

\section{BAIXA EFICIÊNCIA NO USO DOS RECURSOS DE PESQUISA E DESENVOLVIMENTO EM INSTITUIÇÕES PÚBLICAS DE PESQUISA BRASILEIRAS: ANÁLISE DE CADEIAS CAUSAIS}

O paradigma da Inovação Aberta trouxe desafios adicionais ao já complexo cenário brasileiro de CT\&I de recursos escassos e políticas públicas ineficazes. As Organizações de Pesquisa Pública (OPPs) enfrentam obstáculos em relação à limitação imposta por sua natureza pública, leis e regulamentos complexos, estrutura tecnológica e organizacional inadequada e falta de estratégia e prioridade. Além disso, para melhorar seus resultados e recuperar a competitividade, os projetos de Pesquisa \& Desenvolvimento (P\&D) devem ser transdisciplinares e colaborativos, o que geralmente requer um alto volume de orçamento, grandes equipes e estrutura organizacional para Administração e Gestão de Projetos de Pesquisa (AGPP). A baixa eficiência no uso de recursos físicos, financeiros e humanos está dificultando os OPPs de superar a crise financeira e os inexpressivos resultados nacionais de CT\&I. Este estudo objetivou fazer uma análise profunda desse problema macro na perspectiva do Gestor de P\&D como ator social, baseado no método do Planejamento Estratégico Situacional. Os resultados evidenciaram a vastidão do problema e apoiaram a compreensão do jogo social vigente e das frentes de trabalho em que o ator poderia atuar para enfrentar o problema. A principal conclusão é que os OPPs devem levar em conta a capacitação em AGPP para alavancar resultados e influenciar positivamente a arena de políticas de CT\&I.

Palavras-chave: Administração da pesquisa.Gestão de projetos de pesquisa.Instituições públicas de pesquisa.Políticas públicas.Planejamento estratégico situacional.

\section{BAJA EFICIENCIA EN EL USO DE LOS RECURSOS DE INVESTIGACIÓN Y DESARROLLO EN INSTITUCIONES PÚBLICAS DE INVESTIGACIÓN BRASILEÑAS: ANÁLISIS DE CADENAS CAUSALES}

El paradigma de la Innovación Abierta trajo desafíos adicionales al ya complejo escenario brasileño de CT\&I de recursos escasos y políticas públicas ineficaces. Las Organizaciones de 
Investigación Pública (OPPs) se enfrentan a obstáculos en relación con la limitación impuesta por su naturaleza pública, leyes y reglamentos complejos, estructura tecnológica y organizativa inadecuada y falta de estrategia y prioridad. Además, para mejorar sus resultados y recuperar la competitividad, los proyectos de Investigación y Desarrollo (I\&D) deben ser transdisciplinarios y colaborativos, lo que generalmente requiere un alto volumen de presupuesto, grandes equipos y estructura organizacional para la Administración y Gestión de Proyectos de Investigación (AGPI). La baja eficiencia en el uso de recursos físicos, financieros y humanos está dificultando que las OPPs superen la crisis financiera y los inexpresivos resultados nacionales de CT\&I. Este estudio tiene como objetivo realizar un análisis profundo de este problema macro en la perspectiva del Gestor de I\&D como actor social, basado en el método de la Planificación Estratégica Situacional. Los resultados evidenciaron la magnitud del problema y apoyaron la comprensión del juego social vigente y de los frentes de trabajo en que el actor podría intervenir para enfrentar el problema. La principal conclusión es que las OPPs deben tener en cuenta la capacitación en AGPP para aprovechar los resultados e influir positivamente en la arena de las políticas de CT\&I.

Palabras clave:Administración de la investigación.Gestión de proyectos de investigación.Instituciones públicas de investigación.Políticas públicas.Planificación estratégica situacional.

\section{INTRODUCTION}

The competitive advantage and prosperity of developed countries are directly related with their ability to reconfigure knowledge and explore their technological competencies, which intensified Research and Development (R\&D) activities and international competition in the last decades (CHRISTENSEN, 2006; GIBBONS et al., 1994). The complexity of the knowledge capacity building and the current challenges imposed by societal demands require a new way of combining ideas and doing science that considers R\&D an open system, which is called "Open Innovation" by Chesbrough (2006). In this paradigm, the partnerships and collaborations have a crucial role in the process of combine skills and knowledge, search and create new markets and share risks in order to find the most impacting solutions. R\&D projects with big and mixed teams (several firms and countries), transdisciplinary knowledge and the high volume of budget and assets increases a lot the challenges already in place. Investments in organizational and institutional innovations, in addition to technological innovations, are 
essential to less developed countries overcome the lack of resources and lateness in the evolvement of the Science, Technology and Innovation (ST\&I) in Brazil (SALLES-FILHO; PEDRO; MENDES, 2007). In this scenario, the Public Research Organizations (PROs) are important actors in the economic development policies and international competitiveness, helping the introduction of innovations through the connection with other organizations and companies to enable knowledge application and reduction of uncertainties (CGEE, 2010).

According to UNESCO (2015), science and technology investment in Brazil is smaller than important emerging economies such as China and South Korea. Although gross R\&D expenditures in Brazil have doubled from 2004 to 2012 (when it reached the rate of $1.16 \%$ of GDP), the report had already predicted a negative impact on R\&D spending as a result of the Brazilian economic crisis. More recent news indicates that at the end of March 2017, the budget of the Ministry of Science, Technology, Innovation and Communication (MCTIC) was the lowest of the last 12 years (ANGELO, 2017; MARQUES, 2017). In addition, the national R\&D strategy is not synchronized with the economic and social challenges, resulting in an inexpressive impact to the society and lower bargaining power of the science in the political and financial arena (DE NEGRI, 2016).

Furthermore, the national public research institutions and universities need to attend a variety of regulations in federal and state level that, the most of the times, are not different from the regulations of ordinary companies, which imposes bureaucratic structures, obligations, restrictive legal models and irregular flows of funds that bring major administrative difficulties and jeopardize the relevance of these institutions (RIBEIRO; SALLES-FILHO; BIN, 2015; UNESCO, 2015). At the same time, these institutions and universities are always being questioned about the destination of the public resources, which is not a simple task since $R \& D$ activities and knowledge advancement results are not always tangible (MARQUES, 2016).

The complexity and red tape issues of the Brazilian laws and regulations are the results of the implementation of several public policies in ST\&I in the attempt to stimulate the development of these respective areas, unfortunately without significant achievements until the moment as briefly commented before. The implementation of public policies for ST\&I is a challenge due to the necessity of coordination and integration of policies in several other areas such as economic and social development. Such transdisciplinarity of ST\&I also brings difficulties to understand correctly and deeply the root causes of the current problems which impact directly in the adequate elaboration of public policies in the area, and, consequently in the performance of the PROs. 
The correct understanding of a problem, its causes, and symptoms can avoid not only waste of time and resources, but also that its aggravation becomes a future crisis (IIDA, 1993). Complex problems require specific methods and models that take into account the dynamism and constant changes in reality. The Situational Strategic Planning (SSP) method, proposed by Carlos Matus in 70's, criticizes the traditional planning, avoiding a deterministic, generic and reductionist approach and contemplates the diversity of interests, goals, and actors of the social game (FIGUEIREDO FILHO; MÜLLER, 2002; FORTIS, 2010; IIDA, 1993). Another important factor to understand a problem is the perspective being considered, it means, who is the social actor that recognizes the problem, since a problem for someone can be an opportunity for others, besides the governability of this actor. The governability capacity of the actor is related to the control of the resources needed in the social game interaction, not only economical but also political resources (AZEVEDO, 1992; IIDA, 1993). Different of the traditional planning where the subject is the State and the object controlled by it is the socio-economic reality, in the SSP the subject and object cannot be distinguished, the planner subject is also the planned object. Therefore, the capacity of control of the actor in the declared problem can't be assured, it means, there are levels of governability according to the actor and the scenario of the situation (MATUS, 1996).

The aim of this article is to analyze the causes and consequences of the problem "Low efficiency in the usage of financial, physical and human resources in R\&D projects in PRO in Brazil” in the R\&D Manager perspective, using SSP approach.

The motivation of this study is to comprehend how the PRO can deal with the adverse context of the Brazilian ST\&I area to capture resources, make better use of them, and, consequently, to improve their efficiency and bring more impacting results to the society. In this study it is considered that improve the efficiency of a Brazilian PRO involves to be able to get funding, develop partnerships for R\&D projects, and also optimize the use of resources. The social actor that controls the organizational resources and has more governability to make decisions and implement actions from inside a PRO is the R\&D Manager, which justifies the selection of this perspective in the study analysis.

\section{THEORETICAL BACKGROUND}

\subsection{ST\&I PUBLIC POLICIES}


Borrás and Edquist (2014) explain that innovation is a complex, diverse and widespread human activity and there are many types of regulations and regulatory areas for innovation that can be considered according to the desired effects in the society. There are five core regulatory areas in an innovation system: immaterial assets and knowledge appropriation regulations, fair market competition regulations, financial and corporate governance regulations, consumer protection and product liability regulations, and environmental protection regulations. The institution formed by the combination of these regulations for innovation aims to provide incentives for investment, reduce uncertainties and risks and manage conflicts and cooperation. The innovation policies dictate the rules of the game related to the interactions between the socio-economic actors in the innovation process with the purpose of promoting the innovation activity or change the trajectory of innovation processes (BORRÁS; EDQUIST, 2014). The authors highlight three systemic problems related to the design of innovation policy: (i) the effects of innovation are unpredictable due to the actors behavior; (ii) it is necessary to find the better cost-benefit relation of the regulation when considering the interests involved and social benefits related, and (iii) policies need to be adaptative and to change over time.

According to Edquist (2015, p. 2), "the choice of innovation policy instruments is a very important part of the formulation of an innovation policy" and often it is necessary a combination of instruments to be used by public organizations to influence the innovation process. The innovation policies can be categorized into two types: supply-push oriented instruments, focused in raise investments in research and innovation, and still based in the outdated linear model of ST\&I (in which the knowledge is generated mainly by the academic researchers), and demand-based that aims to increase the demand for innovations and improve the articulation of demand to the arising and diffusion of innovations. The supply-side policy tools are equity support, fiscal measures (i.e. tax reductions), support for public sector research (p.e. funding and grants), support for training and mobility, grants for industrial $R \& D$, information and brokerage support and networking measures. The second type, demand-side policy tools, have focus in the state capacity building for policy-making to improve technological capacity of firms instead of finance measures, and involve the implementation of systemic policies related to cluster development and supply chain, implementation of regulations and standards related to technology platforms and innovation targets, public procurement, and subsidies and tax incentives for private demand (EDLER; GEORGHIOU, 2007; EDQUIST, 2015; PACHECO; BONACELLI; FOSS, 2017). 
The science and technology policies have a relevant role in the building of the innovation systems in Latin America developing countries (BASTOS; COOPER, 1995). However, the lack of adequate development strategy in Brazil cause that it still predominate the design of ST\&I policies based in supply-side policy tools, which are insufficient to stimulate investments in $R \& D$ and innovation that have relevant effect in the enhancement of competitiveness, and to take economy out of stagnation (ARBIX, 2019; BASTOS; COOPER, 1995; EDLER; GEORGHIOU, 2007). Arbix (2019) mentions how challenging is to find the most effective approach for decision-making and policy implementation in early catch-up phase to push a paradigm shift in the Brazilian economy due to the complex combination, engagement and evolvement of relevant elements: institutions, education and technological capacity of firms. The author also emphasizes the importance of coordination mechanisms, priority-based and results-oriented policies to the effectivity of the initiatives in the area. Unfortunately, the government haven't been capable to advance in the solution of this puzzle until the moment, since the disarticulation of economic and science and technology policies and absence of strong institutions were already mentioned as a relevant cause of the insignificant improvements in the development of ST\&I more than 20 years ago by Bastos and Cooper (1995), when detailed the history of the science and technology policies in Brazil.

Innovation policies started to be a consistent concern only in the 2000s in Brazil with the approval of the Innovation Law (10.973/2004), followed by other laws and regulations. In 2016, a revision of the Innovation Law, entitled the New Landmark of ST\&I (13.243/2016) was approved, together with changes in a group of related laws, in an attempt of adjustments and simplification of controls to bring agility and flexibility in several processes such as importation, procurement, and contract management, and also trying an incipient orientation to demand-side measures (PACHECO; BONACELLI; FOSS, 2017). Although Pacheco, Bonacelli and Foss (2017) have pointed some remaining issues in the last enacted laws and the challenging Brazilian context regarding policies disconnection, they affirm these initiatives can still contribute to the development of innovation system and science and technology in general. It is necessary a time to evaluate the results and impacts of the implementation of the instruments enabled by the reviewed laws, including the establishment of arrangements and engagement of the actors involved. In this scenario, the funding agencies are important actors in the elaboration of calls for research projects that makes use of the new regulatory possibilities, and each research organization must continuously study and know the regulatory 
updates to try to achieve more agility and efficiency in their administrative processes and scientific activities (PACHECO; BONACELLI; FOSS, 2017).

\subsection{SITUATIONAL STRATEGIC PLANNING (SSP)}

The Situational Strategic Planning (SSP) proposed by Carlos Matus (1996) is a tool to enable the government representative to deal with shared power and conflict situations of the social game, considering the uncertainty of the future and projection of scenarios and possible actions, which is not carried out effectively in the traditional planning. The process of SSP is organized in four moments, that are not isolated and delimited but each moment predominates in accordance with the development stage of the planning. The four moments are explanation moment (M1), normative-prescriptive moment (M2), strategic moment (M3) and operationaltactical moment (M4) (AZEVEDO, 1992; FIGUEIREDO FILHO; MÜLLER, 2002; MATUS, 1996). In the M1 the reality is explained, in the M2 the design of the plan is proposed, in the M3 the strategy is elaborated and in M4 decisions are taken and the plan is executed (MATUS, 1993).

The base of the SSP is the comprehension of the present, the explanation of the current reality. The explanation of reality is a diagnosis interpreted by the values and life experience of an actor (MATUS, 1996). The goal of the explanation moment (M1) is to clarify the reality through the situational explanation in the perspective of a specific social actor, recognizing that his reality is not unique (FIGUEIREDO FILHO; MÜLLER, 2002). The macro problem is a momentary result of a partial problem that is relevant to the actor in a concrete situation, and this macro problem coexists and interacts with other partial problems of the social game. After the macro problem be decomposed in descriptors and consequences, it is analyzed and expressed in causes and represented graphically in a situational flowchart (IIDA, 1993; MATUS, 1996).

The goal of the normative moment (M2) is to define an action plan to attack the critical nodes found during the M1 aiming changes in the initial situation to achieve the goal situation. The plan works with the concept of operation that is compounded by the definition of required resources (economic or not), products, and results (political, economic, cognitive, organizational or cultural impact), and should be flexible to deal with the uncertainties (AZEVEDO, 1992; MATUS, 1996). 
In the strategic moment (M3) is built the viability and strategy of the plan, to be possible in future what is not possible today (MATUS, 1996). According to the author, the strategy is related to the exploration of possibilities of cooperation to minimize conflicts. The strength of the involved actors is very relevant for the strategy and is compounded by five elements: personality, passion, resources control and ownership, expertise, and scientific and technological knowledge domain. At this moment, the analysis aim to overcome the obstacles to the changes be effective (AZEVEDO, 1992).

The tactical-operational moment (M4) is the execution of the plan that involves continuous evaluation of the desired impacts and the current reality to support decision-making and adjustments (AZEVEDO, 1992). According to Matus (1996), this moment requires the creation of a planning and monitoring system based on the situational changes and performance resulted from the actions under implementation.

The study presented in this article is delimited to the M1 and pretend to be a source of information to policymakers engaged in the planning and execution of ST\&I policies.

\subsection{RESEARCH MANAGEMENT AND ADMINISTRATION}

According to Kerridge (2012), Research Management and Administration (RMA) is "the leadership, management or support of research activities".

With the increase of $R \& D$ investments, funding and grants in the postwar era in the United States, and the emergence of the Big Science projects, surge the necessity to adequately manage and administrate research projects with a high volume of budget. Since then, the RMA area is being continuously evolved in the developed countries, where the profession of research administrator is already existent in many universities and research institutes and the community of professionals is organized in national associations (MYERS, 2007). According to Langley and Ofosu (2007), universities usually have dedicated sponsored research support offices with specialists in several areas of the research project life cycle.

The research project life cycle can be divided into two large phases: pre-award and postaward. The pre-award phase represents activities that are executed since the project idea, negotiation, preparation and application of a project proposal, until the project acceptance by a sponsor. The post-award phase starts after the budget release and contemplates all the project management, including resources and finance management until the project accountability, results publishing, technology transfer, audit and closing (ANDERSEN, 2017). The research administration area can also be divided into four main disciplines, according to the Certified Research Administration Body of Knowledge (CRABoK): projects development and 
administration (communication, project proposal, intellectual property, grants and scholarships, ethics), legal requirements and sponsor interface, financial management and general management (procurement, contracts, assets, risks, infrastructure, documents, human resources) (RACC, 2018). As can be noted, the scope of the research administration is very broad and permeates the whole research project life cycle. Because of this, the research administration professional is also very diverse according to its tasks, background, soft skills, seniority, proximity to the researchers and knowledge in funding mechanisms. Poli (2018) commented that most of the time the research administrators are an invisible workforce and not properly recognized. Several frameworks were defined by some professional associations in order to bring more visibility to the profession, support the development skills and career advancement, and achieve better performance (POLI, 2018). The project "Research Administrator as a Profession" (RAAAP) made an extensive mapping of the research administrators with the professional association members worldwide and found several indicators of the maturity of the profession, although differences among regions (KERRIDGE; SCOTT, 2018).

In Brazil, some initiatives started in the 2010 s to promote the importance of RMA profession and related activities. São Paulo Research Foundation (FAPESP), one of the most important public funding agencies in Brazil, created a specialized training program to capacity members of the research institutions about the funding agency procedures since pre-award until post-award phase, called "Training Program for Implementation of an Institutional Support Office for Researchers (EAIP)" (FAPESP, 2018a). In 2013 it was created the Brazilian Research Administration and Management Association (BRAMA) aiming the development and recognition of the research manager and research administrator professionals in the country (BRAMA, 2018).

The open innovation and the necessity of collaborations and transdisciplinarity usually demand projects with an expressive budget and large team size which bring a huge effort of trust building and partnership establishment, intellectual property management, communication management, and project management in general. The researchers are not always prepared to deal with administrative activities beyond the scientific activities, which affects directly the ST\&I performance. This article will bring to the discussion the connection among the challenges and demands of the ST\&I projects with operational aspects of the administration and management of the resources involved, and the importance of the RMA knowledge area in this scenario. 


\section{METHODOLOGY}

This article is a qualitative study that uses elements of the first moment (M1) of the SSP method to support the identification and comprehension of the causes and consequences of the macro problem: "Low efficiency in the usage of financial, physical and human recourses in R\&D projects in PRO in Brazil", in the perspective of the R\&D Manager as social actor.

The SSP method was used in this article in a simplified model to facilitate the visualization of the situational flowchart, without the adoption of categorization of the causes according to their nature and control level as described in Matus (1996). The flowchart presents the following elements: the macro problem, its descriptors, its consequences, and the causal chains (CC) related, as explained in Figure 1. Each CC is compounded by a chain of causes.

Figure 1 - Chain of Causes and Causal Chain Example

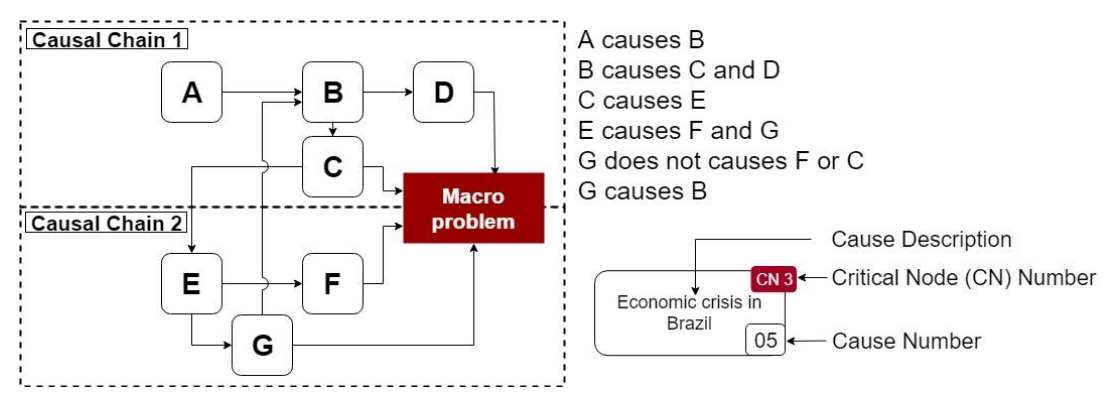

Source: elaborated by author, adapted from Matus (1996, p. 31).

The situational flowchart also highlights the critical nodes $(\mathrm{CN})$. A CN represents a cause where the actor can act directly and effectively to achieve a high-level impact in the descriptors of the macro problem (IIDA, 1993).

In the Results section, the situational flowchart is presented and all its elements described and supported by a literature review.

\section{RESULTS}

\subsection{MACRO PROBLEM DESCRIPTORS AND CONSEQUENCES}

Following the SSP method, the first step is to describe the macro problem"Low efficiency in the usage of financial, physical and human resources in R\&D projects in PRO in Brazil" based in a literature review. There were identified three major descriptors and three 
major consequences to illustrate the macro problem. They are evidenced based in some qualitative or quantitative indicators found in the literature review. The descriptors and consequences are exposed in separated subsections but they are very connected and the same references are sometimes used as justificative for more than one of them.

Descriptor 1. The financial crisis of the ST\&I in Brazil:

Brazil has been facing a huge cut in the budget of the MCTIC in the last decade, which direct impacts in national $R \& D$ results, driving to stagnation and dismantling of laboratories and research institutions (ANGELO, 2017; ESCOBAR, 2019; MARQUES, 2017). Even after a change of government at the beginning of 2019, the ST\&I budget cuts continued in course and may represent $42 \%$ of reduction in funds for scholarships and research if the conditions for federal budget freezing were not reviewed (ESCOBAR, 2019).

Descriptor 2. Red tape and overhead of researchers in administrative and management activities:

A study published in 2017 by National Council of Foundations to Support Federal Institutes of Higher Education and Scientific and Technological Research (CONFIES), called "What does Brazilian researcher think about bureaucracy?", presented that a researcher spends, in average, $33 \%$ of his time to deal with administrative and bureaucracy activities. The participants of the mentioned study also pointed that $85 \%$ of the project management activities are complex and demand huge effort and time, and 39\% answered that are not aware of the last changes in ST\&I law and regulations (CONFIES; MCTIC; SEBRAE, 2017; MONTEIRO, 2017). A recent study about research collaborations reinforces the discomfort of Brazilian researchers with the complexity of the administration of the project resources mainly in large teams due to the challenge of opinion convergence and resources distribution (ODELIUS; ONO, 2019).

Descriptor 3. Institutional and Management limitation of PROs:

The Brazilian historical aspects of socioeconomic development and delayed scientific and technical progress influence in the difficulties and challenges of the government in the formulation of ST\&I public policies adherent to national needs (DE NEGRI et al., 2016). The PROs are treated by Brazilian regulations in most of the times in a very similar way of ordinary companies, it means that the ST\&I specificities are not appropriately managed, which open space to the establishment of inadequate or unnecessary controls, red tape issues and law insecurity (OLIVEIRA et al., 2017; RIBEIRO; SALLES-FILHO; BIN, 2015). Ribeiro et al. (2015) explain that the consequence of the regulatory inadequacy is a huge administrative 
difficulty that put at risk the relevance of PROs. The obstacles faced by PROs increase national research costs and decrease their competitiveness mainly internationally (MONTEIRO, 2017).

In 2004, the government signed the Innovation Law that defined the obligation to create Technology Transfer Offices (TTO) in PROs in an attempt to improve efficiency in the partnership building. Paranhos (2018) study analyzed data from 2007-2015 and concluded that although the increase of the number of TTOs in Brazilian institutions, the number of technology transfer contracts are still inexpressive and the major factor is the lack of financial support to improve the physical and human infrastructure of TTOs.

Consequence 1. Low efficiency of Research, Development and Innovation activities in Brazil:

The first main consequence identified as a result of the inefficient ST\&I public policies, which contribute to the red tape issues and adverse institutional environment of the PROs, is the inexpressive results of Brazil in $R \& D$ and Innovation area when compared to other developing and developed countries.

While Brazil has been presenting a good situation in Scimago Journal \& Country Rank, being at $24^{\text {th }}$ position in the H-index impact (SJR, 2018), the results regarding patents are much more timid. In 2015 Brazil had 381 patents granted by United States Patent and Trademark Office (USPTO) which is much lower than countries such as United States (155k), South Korea (20k) and China (9k) (USPTO, 2015). The 2014 Survey of Innovation (Pintec) performed by the Brazilian Institute of Geography and Statistics (IBGE) pointed a stagnation in the innovation rate and found three factors as main obstacles for innovation by companies: cost, risks and scarce funding sources for innovative activities (IBGE, 2016). Additionally, other studies affirm that the companies are not familiar with the tax incentives to stimulate R\&D investment (CARVALHO, 2010) and that these tax incentive policies are not effective without a continuous strategy and favorable socioeconomic environment to develop and maintain innovative capacity (PACHECO; BONACELLI; FOSS, 2017).

Consequence 2. Inappropriate use of financial, physical and human ST\&I resources:

The low academic and scientific efficiency is directly related to the low administrative efficiency that affects negatively the prospection of opportunities and the management of projects and partnerships. In order to minimize the restrictions, fragilities and legal uncertainty of regulatory frameworks for public-private relations, the new Landmark of ST\&I (13.243/2016) was approved, which brought changes in several other laws related to procurement, imports, contracting and others, but still with few significant results. 
A study performed by Ribeiro, Salles-Filho and Bin (2015) analyzed two PROs and identified limitations related to budgetary and financial management, maintenance and development of human resources, resulting from specific laws that cause low flexibility and autonomy, with a great impact on the performance and competitiveness of these institutions. The public organizational design of PROs has complex forms and multiple hierarchical levels with high control in the movement of personnel and rigid structures resistant to organizational changes, processes, and technologies, which presents a great difficulty in the implementation of improvements (PIRES; MACÊDO, 2006).

\section{Consequence 3. Brazilian companies are not very innovative:}

Complementing the evidences already described in the "Consequence 1" that are also related to this consequence, a study performed by Verde and Miranda (2018) using "The Global Innovation Index" methodology in the period of 2012-2017 noticed that even with some increase in the input index (institution, human capital, infrastructure, market sophistication, and business sophistication), there was a relevant decrease in the output index (knowledge, technology, creativity) which resulted in a -0.30 index of (in)efficiency in innovation in the period. The study also compared the results with the period of implementation of the new Landmark of ST\&I (13.243/2016) and concluded that although some promising advances in the innovation instruments proposed by the law, the most of the companies and organizations are not yet practicing the changes. Other studies corroborated that the companies and institutions are not yet prepared to adopt the changes due to endogenous and exogenous factors and more time is required to evaluate results of the new law (MIRANDA et al., 2019; PACHECO; BONACELLI; FOSS, 2017).

\subsection{SITUATIONAL FLOWCHART}

After the clarification of the descriptors and consequences, the macro problem was analyzed in the perspective of the R\&D Manager as a social actor. The analysis of the macro problem resulted in the identification of 42 arguments organized in six causal chains (CC). Three critical nodes $(\mathrm{CN})$ were also identified. The $\mathrm{CC}$ have intersections, and it was not easy to define the separation among them. We followed the chain of causes related to the topic of each one of the broader causes found, trying to identify the major topics and facilitate the analysis. The Situational Flowchart with the analysis result is presented in Figure 2. 
In the following subsections, each $\mathrm{CC}$ and $\mathrm{CN}$ is explained based on the literature review. 
Figure 2 - Situational Flowchart

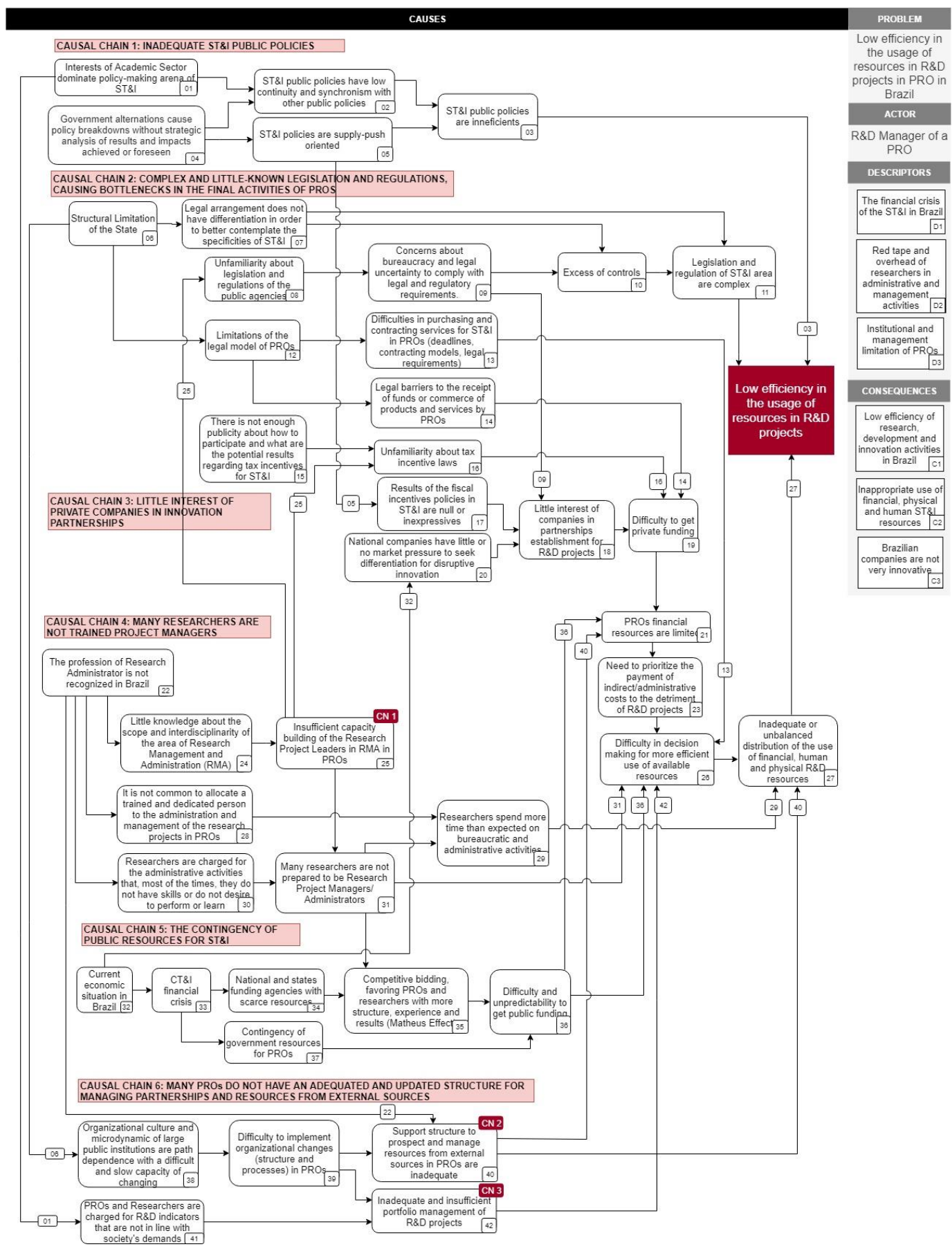

Source: elaborated by the author.

\subsection{CAUSAL CHAINS}

Each CC identified in the study is justified below through a list of main evidences of their causes found in literature and media. 


\section{1. Inadequate ST\&I public policies:}

The difficulties in the establishment of adequate ST\&I public policies resulted in a group of innovation policy instruments that are inadequate or disconnected and don't achieve the desired impact in the demand for innovation and partnerships in Brazil. See details in Table 1.

Table 1 - Justifications for CC 1 - Inadequate ST \&I public policies

\begin{tabular}{|c|l|c|}
\hline Id & $\begin{array}{l}\text { Justifications } \\
\text { CC1.1 }\end{array}$ & $\begin{array}{l}\text { Causes } \\
\text { Supported } \\
\text { innovation and partnerships among public and private actors, since they are } \\
\text { predominantly composed by supply-push oriented instruments (PACHECO; } \\
\text { BONACELLI; FOSS, 2017). }\end{array}$ \\
\hline CC1.2 & $\begin{array}{l}\text { The themes of ST\&I in Brazil are still very connected with universities and research } \\
\text { institutes and MCTIC governance end up privileging the interests of the academic sector, } \\
\text { being distant from the needs of the productive sector, which makes difficult to engage } \\
\text { economic area to guarantee the funding (MARQUES, 2017). }\end{array}$ & 05,03 \\
\hline CC1.3 & $\begin{array}{l}\text { The Brazilian government has an institutional immaturity and difficulties to prepare and } \\
\text { maintain industrial and innovation public policies working for long periods. The difficulty } \\
\text { to improve development policies are result of the disconnection and constant risk of } \\
\text { discontinuity of the implementation and coordination of industrial policies, ST\&I } \\
\text { policies, agricultural and environmental policies during the government transitions } \\
\text { (ARBIX et al., 2017; CRESTANA; MORI, 2015). }\end{array}$ & 02,04 \\
\hline
\end{tabular}

Source: elaborated by the author.

CC 2. Complex and little-known legislation and regulations, causing bottlenecks in the final activities of PROs:

The public organizations, in general, have specificities such as paternalism in the relations, overvaluation of hierarchy and stability, attachment to routines, rules and power, that influences directly their internal processes, values, human resource policies and the culture for innovation. The structure of the public organizations are complex, rigid and centralized instead of oriented for efficiency, and requires a structural and cultural transformation. The PROs are impregnated with issues of the public sphere jointly with ST\&I policies arena, which delimitates a unique and intricate scenario. See references and detailed justifications in Table 2.

Table 2 - Justifications for CC 2 - Complex and little-known legislation and regulations, causing bottlenecks in the final activities of PROs 


\begin{tabular}{|c|c|c|}
\hline Id & ions & $\begin{array}{c}\text { Causes } \\
\text { supported }\end{array}$ \\
\hline $\mathrm{C} 2.1$ & $\begin{array}{l}\text { The inflexibility and lack of autonomy of public organizations, presents the following } \\
\text { characteristics regarding the culture of public organizations as relevant causes of these } \\
\text { issues: bureaucratism, political interference, aversion to entrepreneurship, centralized } \\
\text { authoritarianism, paternalism, and management discontinuity (PIRES; MACÊDO, 2006). }\end{array}$ & 6 \\
\hline $\mathrm{C} 2.2$ & $\begin{array}{l}\text { Despite the ST\&I challenges regarding open innovation and scarce funding, the legal } \\
\text { model and political influences are important determinants of the operational } \\
\text { difficulties and limitations of PROs. The study of the Report of the Center for Strategic } \\
\text { Studies and Management (2010) identified } 17 \text { different types of legal identities of PROs } \\
\text { in public administration, business entities (including public companies) and non-profit } \\
\text { entities. The limited flexibility and autonomy imposed by the legal identity of these } \\
\text { organizations affect directly their management, administrative and political capabilities. }\end{array}$ & 12 \\
\hline $\mathrm{CC} 2.3$ & $\begin{array}{l}\text { TheBrazilian regulations don't manage appropriately the ST\&I specificities of } \\
\text { PROs, applying in many cases the same rules of ordinary companies (RIBEIRO; } \\
\text { SALLES-FILHO; BIN, 2015). Salles-Filho and Bonacelli (2010, p. 199) pointed the } \\
\text { inefficiency of the current ST\&I mechanisms and instruments that "are not well-suited to } \\
\text { research institutions" and complemented that "there is little knowledge about how to make } \\
\text { best use of them or the implications of their use, and the instruments are rarely used } \\
\text { because they entail almost radical changes to the managerial organization of most } \\
\text { institutions, especially public ones." }\end{array}$ & 07 \\
\hline $\mathrm{CC} 2.4$ & $\begin{array}{l}\text { The procurement is one of the processes that presents more difficulties to be } \\
\text { performed by PROs because of the legislation and control agencies requirements to } \\
\text { avoid opportunism and corruption which limits the options of suppliers and products, } \\
\text { increases prices and decreases products and services quality and delivery conditions. In } \\
\text { R\&D projects the purchasing requirements are in many times very specific with dispense } \\
\text { of a bid which becomes the purchasing process very trick to not break the law. } \\
\text { Importation, capture funding and sell products and services are also very restricted } \\
\text { procedures for public organizations for the same reasons. Even adopting alternatives to } \\
\text { deal with contracts and purchasing using third-party services of foundations, the } \\
\text { transaction costs regarding internal controls and audit are not insignificant } \\
\text { (MONTEIRO, } 2017 \text {; RIBEIRO; SALLES-FILHO; BIN, 2015). }\end{array}$ & 13 , \\
\hline $\mathrm{CC} 2.5$ & $\begin{array}{l}\text { The partnership building is another important and also challenging process for the } \\
\text { R\&D and Innovation projects due to strategic and financial purposes (CHESBROUGH, } \\
\text { 2006; HAGEDOORN, 2002). The establishment of contracts of technical cooperation and } \\
\text { intellectual property is the tool to deal with the risks and uncertainty of R\&D projects and } \\
\text { minimize opportunism and law insecurity, which usually increases controls and } \\
\text { transaction costs (OLIVEIRA et al., 2017). }\end{array}$ & $09,10,11$ \\
\hline
\end{tabular}




\begin{tabular}{|l|l|c|}
\hline CC2.6 & $\begin{array}{l}\text { There is a greater expenditure of effort and time in the research project management } \\
\text { activities by the principal investigators due to the complexity and lack of knowledge } \\
\text { about ST\&I legislation and regulatory changes (CONFIES; MCTIC; SEBRAE, 2017). }\end{array}$ & 08 \\
\hline CC2.7 & $\begin{array}{l}\text { Tax incentives have limited extent because of the not-innovative nature of the } \\
\text { companies and their lack of knowledge about how to use them (CARVALHO, 2010). }\end{array}$ & 15,16 \\
\hline
\end{tabular}

Source: elaborated by the author.

The causes not listed in Table 2 are explained by the consequences of the unfolding of the already justified causes. The difficulties to capture funding or use tax incentives (cause 19) imply in the limitation of financial resources of the PROs (cause 21), jointly with the contingency of ST\&I public resources (to be explained in CC 5) and lack of adequate structure to capture and manage external funding (to be explained in CC 6). The limited ST\&I budget (cause 23) affects directly in the financial resources for R\&D projects, because of the competition with fix expenses related to indirect and administrative costs

Summarizing, the R\&D Manager has a huge decision-making challenge (cause 26) to achieve the most efficient use of resources, considering:

- $\quad$ Purchasing and hiring challenges regarding restrictive legislation and difficulties and delays to find the best compliant alternatives.

- $\quad$ Planning difficulties due to unpredictability to get public funding because of contingency, financial resources competition among organizations and uncertainty about resources availability (to be better explained in CC 5).

- Lack of preparation of R\&D Manager and/or Principal Investigator to perform administrative and management activities which impact in lack of strategic planning and adequate decision-making in the use of resources (to be better explained in CC 4).

- Inadequate management of Projects Portfolio and Resources prioritization, also as a consequence of the lack of preparation and strategic view (to be better explained in CC 6).

The inefficient use of financial, physical and human resources are directly related to inadequate decision-making performed by the Principal Investigator and/or R\&D Manager (cause 27). The end of this causal chain (composed by the nodes 19, 21, 23, 26 and 27) is an unfolding of the first causes of the chain, and it is common and repeated in the next causal chains (CC 3, CC4, CC5, and CC6).

CC 3. Little interest of private companies in innovation partnerships:

The lack of government pressure due to the inefficiency of public policies is an relevant cause of the conservative behavior of the Brazilian firms. See details in Table 3. 
Table 3 - Justifications for CC 3 - Little interest of private companies in innovation partnerships

\begin{tabular}{|c|l|c|}
\hline \multicolumn{1}{|c|}{ Id } & Justifications & $\begin{array}{c}\text { Causes } \\
\text { supported }\end{array}$ \\
\hline CC3.1 & $\begin{array}{l}\text { The Survey of Innovation (Pintec) and several articles evidenced the inefficiency of } \\
\text { ST } \text { Ievelopment (IBGE, 2016). See also CC1.1 and CC2.5. }\end{array}$ & 17,18 \\
\hline CC3.2 & $\begin{array}{l}\text { The role of the state is essential in the funding of ST\&I activities due to uncertainties of } \\
\text { the R\&D and innovation processes and the imperfections of the technology market } \\
\text { (BASTOS, 2003; OECD, 2016). However, in addition to being insufficient, public } \\
\text { funding has been reduced due to the crisis. There is a general understanding that in Brazil, } \\
\text { companies do not recognize that greater investments in R\&D bring greater } \\
\text { competitiveness, and there is also no government pressure through approppriate ST\&I } \\
\text { public policies (BONACELLI, 2013). }\end{array}$ & 20 \\
\hline CC3.3 & $\begin{array}{l}\text { Some reasons for the conservative behavior of the Brazilian firms are protectionism, } \\
\text { R\&D and innovation costs and the complex business environment (FRISCHTAK, 2019). }\end{array}$ & 20 \\
\hline
\end{tabular}

Source: elaborated by the author.

The end of this causal chain (composed by the nodes 21, 23, 26 and 27) has already been explained in the $\mathrm{CC} 2$.

CC 4. Many researchers are not trained project managers:

The generation of innovations doesn't result only from scientific and technological activities. Other types of activities support R\&D projects, strengthen their learning capacities and enable institutional changes required to adapt them to the new products and services. The ST\&I planning and management is implicated by three elements that differentiate them from other planning and management processes: indeterminacy of the results of a research project and innovation process; the profile of the professionals and culture shared by them since researchers are usually highly qualified, creative and proactive and require constant communication and relationship with peers and partners; and multi-institutionality that is result of the increase of inter-organizational collaborations. The multi-institutionality requires of PROs the capacity to coordinate the interaction of several actors in the decision-making process, to deal with a variety of research profiles, to manage conflicts between research and management demands, and to create mechanisms to enable knowledge creation and appropriation (BIN; SALLES-FILHO, 2008). The technical and scientific leadership is not 
enough to manage ST\&I institutions and projects because of the complexity of the innovation system (SALLES-FILHO; BONACELLI, 2010). See some evidences in Table 4 about the lack of knowledge and capacity in administrative and management activities in PROs.

Table 4 - Justifications for CC 4 - Many researchers are not trained project managers

\begin{tabular}{|c|c|c|}
\hline Id & Justifications & $\begin{array}{c}\text { Causes } \\
\text { supported }\end{array}$ \\
\hline CC4.1 & $\begin{array}{l}\text { The execution of administration and management activities of research projects } \\
\text { requires specific knowledge that usually the researchers are not prepared, which } \\
\text { demands, most of the times, higher effort or rework that become an unplanned additional } \\
\text { burden when accumulated with scientific activities (OLIVEIRA et al., 2017). } \\
\text { Furthermore, the preparation of project proposals and management of funded } \\
\text { projects require additional knowledge about the funding agencies processes in addition } \\
\text { to the internal processes of PROs. The lack of knowledge about these processes and } \\
\text { their implications inhibits the prospection of new external opportunities of funding } \\
\text { by researchers (CUNNINGHAM et al., 2014). }\end{array}$ & $25,30,31$ \\
\hline CC4.2 & $\begin{array}{l}\text { The already mentioned survey about bureaucracy pointed out that researchersspend } \\
33 \% \text { of their time with administrative and bureaucratic activities (CONFIES; } \\
\text { MCTIC; SEBRAE, 2017). See also CC2.6. }\end{array}$ & $29,30,31$ \\
\hline CC4.3 & $\begin{array}{l}\text { Although the ST\&I specificities and administrative and managerial complexity, in most } \\
\text { of the developing countries, such as Brazil, the research administrator profession in } \\
\text { unknown (KERRIDGE; SCOTT, 2018) and often the researcher accumulates } \\
\text { management, administrative and scientific activities with minimal support of other } \\
\text { organizational departments, and most of the times with no financial resources to } \\
\text { implement such administrative team and structure (more details in CC 6). }\end{array}$ & 22,24 \\
\hline
\end{tabular}

Source: elaborated by the author.

The end of this causal chain (composed by nodes 26 and 27) has already been explained in the $\mathrm{CC} 2$.

\section{5. The contingency of public resources for ST\&I:}

The article have alread mentioned the Brazilian financial crisis and the reduced budget to support ST\&I activities. The Table 5 presents some references about the cascade impact in PROs and funding agency budgets. This situation increases the competition for resources among researchers and research institutions, and exacerbates the Mathew effect, coined by Merton (1968). The Mathew effect consists in giving greater recognition and credit for the 
already known senior researchers due to the reward system of the scientific community, which ends up giving more advantage and concentrating resources in a group of the most prominent researchers and institutions (BARBOSA, 2017).

Table 5 - Justifications for CC 5 - The contingency of public resources for ST\&I

\begin{tabular}{|c|c|c|}
\hline Id & Justifications & $\begin{array}{c}\text { Causes } \\
\text { supported }\end{array}$ \\
\hline CC5.1 & $\begin{array}{l}\text { Brazil has the lowest ST\&I budget of the last } 12 \text { years in Brazil, which direct impacts } \\
\text { in national R\&D results, driving to stagnation and dismantling of laboratories and } \\
\text { research institutions (ANGELO, 2017; ESCOBAR, 2019; MARQUES, 2017). }\end{array}$ & 33 \\
\hline CC5.2 & $\begin{array}{l}\text { Science associations published a letter presenting their concern about the contingency of } \\
42.27 \% \text { of the MCTIC in } 2019 \text { that affects several public funding agencies, such as the } \\
\text { National Council for Scientific and Technological Development (CNPq) (JORNAL DA } \\
\text { CIÊNCIA, 2019; SBPC et al., 2019). The financial crisis permeates all areas, not only } \\
\text { ST\&I. There are many PROs funded by a portion of the budget from other ministries, } \\
\text { such as the case of the Brazilian Agricultural Research Corporation (Embrapa), that } \\
\text { depends of the Brazilian Ministry of Agriculture, Livestock, and Food Supply (MAPA) } \\
\text { that have a contingency of more than } 30 \% \text { of the budget for } 2019 \text { (GAZETA DO POVO, } \\
\text { 2019). The Ministry of Mines and Energy (MME), that has a relevant role for the national } \\
\text { sovereignty, supports several research activities and had a contingency of } 80 \% \text { of the } \\
\text { budget in the same year (SBPC et al., 2019). }\end{array}$ & $32,34,37$ \\
\hline CC5.3 & $\begin{array}{l}\text { The lower ST\&I budget impacts directly in less public funding opportunities that tend } \\
\text { to be more competitive. Report about FAPESP activities in } 2017 \text { informed that the } \\
\text { funding agency received } 19 \text { thousand proposals of scholarships and project grants, and } \\
\text { were approved } 10 \text { thousand proposals, about a half. Only } 3 \text { thousand approved proposals } \\
\text { were related to project grants. Remembering that FAPESP is the state agency with a } \\
\text { higher budget and also a higher number of research institutions covered in Brazil } \\
\text { (FAPESP, 2018b). }\end{array}$ & 35,36 \\
\hline
\end{tabular}

Source: elaborated by the author.

The end of this causal chain (composed by the nodes 21, 23, 26 and 27) has already been explained in the $\mathrm{CC} 2$.

CC 6. Many PROs do not have an adequate and updated structure for managing partnerships and resources from external sources:

Due to the several difficulties already exposed in this article, the progress of research in Brazil has been severely impacted. The results are a deficient structure of research including 
technological, organizational and administrative aspects (SALLES-FILHO; PEDRO; MENDES, 2007). Table 6 presents references that justify the causes for this affirmation.

Table 6 - Justifications for CC 6 - Many PROs do not have an adequate and updated structure for managing partnerships and resources from external sources

\begin{tabular}{|c|c|c|}
\hline Id & cations & $\begin{array}{c}\text { Causes } \\
\text { supported }\end{array}$ \\
\hline CC6.1 & $\begin{array}{l}\text { PROs face pressure to attend the expectations of the state, society, firms and several } \\
\text { other actors of the national innovation system. They present three types of constraints } \\
\text { that limit PROs autonomy: legal framework regarding public domain; political } \\
\text { influence of government authorities and internal institutional culture (inertia) (SALLES- } \\
\text { FILHO; BONACELLI, 2010). The same study presented several problems faced by } \\
\text { PROs: legal and fiscal restrictions to renew scientific and managerial staff, difficulties in } \\
\text { the establishment of a career plan and performance assessment, difficulties to establish } \\
\text { networks that enable real leverage of core competencies in research and services activities } \\
\text { such as selling products and services and development of competitive projects, difficulties } \\
\text { to professionalize and optimize intellectual property and technology transfer capabilities. }\end{array}$ & 3 \\
\hline CC6.2 & $\begin{array}{l}\text { The disconnection between science and technology system and the demands of society } \\
\text { was presented in CC1.2 and is also evidenced by the low number of researchers employed } \\
\text { by firms in Brazil. This problem can also be illustrated by the mostly currently used R\&D } \\
\text { indicators that reflect a limited scope of the results and impacts with a focus in } \\
\text { academic and scholar results(such as publications and patents) instead of the social } \\
\text { impact of the scientific outcome (TOOM, 2017). }\end{array}$ & 41 \\
\hline CC6.3 & $\begin{array}{l}\text { The governance strategy and decision-making capacity impacts the organization's } \\
\text { competitiveness and is directly related to the planning and management processes (BIN; } \\
\text { SALLES-FILHO, 2008). Although the ST\&I current scenario demands organizational } \\
\text { changes to enable management capacity building, the research institutions have } \\
\text { difficulties to implement management practices because of their nature, environment } \\
\text { and specific culture that impose constraints to internalize such routines } \\
\text { (ALBUQUERQUE; BONACELLI, 2014). }\end{array}$ & $38,39,40$ \\
\hline CC6.4 & $\begin{array}{l}\text { About the fragilities of the strategic and portfolio management capacity of PROs, } \\
\text { Penteado et al. (2014) and Buainain (2018) studied the Brazilian Agricultural Research } \\
\text { Corporation (Embrapa) and identified a pulverization of the agenda in many projects } \\
\text { with low impact, a dispersion of resources and loss of focus in the company mission. } \\
\text { De Negri (2015) punctuated that only } 30 \% \text { of public resources for R\&D are discriminated } \\
\text { to solve specific problems (p. e. in health and agriculture area). }\end{array}$ & 41,42 \\
\hline
\end{tabular}


Source: elaborated by the author.

The end of this causal chain (composed by the nodes 21, 23, 26 and 27) has already been explained in the $\mathrm{CC} 2$.

\subsection{CRITICAL NODES}

Following the SSP method, the next step after the causal chain analysis in the situational flowchart is the identification of the critical nodes $(\mathrm{CN})$. The critical nodes are causes that have a high degree of impact on the descriptors, are favorable politically in the current national and institutional context and the actor has governability to act on them (IIDA, 1993).

The following CNs were identified:

CN 1) Insufficient capacity building of research project leaders in RMA in PROs (Cause 25).

$\mathrm{CN} 2$ ) Support structure to prospect and manage resources from external sources in PROs are inadequate (Cause 40).

$\mathrm{CN} 3$ ) Inadequate and insufficient portfolio management of the $R \& D$ projects (Cause 42).

The CN 1 is originated in the CC 4 "Many researchers are not trained project managers" and is input at the beginning of two other causal chains (CC 2 and $\mathrm{CC} 5)$ which means NC 1 impacts three causal chains. This cause can be attacked in a relatively easy way by $R \& D$ Manager through the elaboration of a Training Plan and a Human Resources Management Plan that address the capacitation of researchers and/or other R\&D supporting professionals in administrative and management skills required by $R \& D$ projects.

The CN 2 and CN 3 are originated in CC 6 "Many PROs do not have an adequate and updated structure for managing partnerships and resources from external sources" and are input of the causes 21, 26 and 27 that appear in the end of several causal chains (CC 2, CC 3, CC 4, CC 5) which means CN 2 and CN 3 impact five causal chains. These critical nodes are related to organizational changes inside PROs. Although PROs have several exogenous limitations due to their public identity, the R\&D Manager usually has the autonomy to implement changes in internal processes regarding strategic management and portfolio and project management to try to improve decision-making, minimize transaction costs and maximize efficiency in the use of public resources. 
After the complete analysis of the situational flowchart, its CCs and CNs, it is possible to infer that: (i) if the PRO has its strategy and priorities defined, reviewed according to the last government updates and disclosed for the whole organization, (ii) if the PRO team has appropriate administrative and management structure to support $R \& D$ projects and (iii) if PRO team is trained and aware of the possibilities and limitations of the ST\&I legislation and public policies, then they will have the required instruments to face the tortuous ground of the ST\&I in Brazil and make better use of their resources. For sure the social game is not that simple, but this result permits to have more confidence to define a feasible and governable action plan and give a small but also an important step in the virtuous cycle of the continuous improvement of the efficiency of ST\&I in Brazil.

\section{DISCUSSION}

Most of the causes identified in the situational flowchart are external to the PROs environment, and, consequently, are out of the governability of their management team. However, it was possible to identify three critical nodes that represent causes that are internal to the PROs environment and, together, have a direct impact on five causal chains. All the critical nodes are related to the organizational structure to administrate and manage research projects: Insufficient capacity building of research project leaders in RMA in PROs (CN 1), Support structure to prospect and manage resources from external sources in PROs are inadequate (CN 2), and Inadequate and insufficient portfolio management of the R\&D projects $(\mathrm{CN} 3)$.

Although some relevant limitations of PROs due to their public nature, their management board have some autonomy to make decisions and promote changes to their institutional paths. Study conducted by Salles-Filho and Bonacelli (2010) found three types of PROs: path finders (found new ways to attend their mission), path founders (initiated new trajectories possibly changing their mission) and path losers (no relevant action to catch up current ST\&I environment demands), and affirmed that there were no public policies to help PROs in this redirection during the period studied, which emphasize the importance of internal decision-making. The PROs that knew how to redirect their trajectories and to show their social importance to society, had the opportunity to be recognized and have some support of the government eventually (SALLES-FILHO; BONACELLI, 2010). Review PROs organization 
and strategy according to the ST\&I scenario and in the appropriate timing can be the salvation of the organization in a crisis as in the present days.

The strategy of the PROs should go beyond the political interests and consider the revision of processes and capacitation plan of the employees to achieve the necessary efficiency to make the better use of resources in research projects. It means that it is important to understand the current requirements to be a relevant player in the Open Innovation scenario. This study concludes that the implementation and operationalization of adequate RMA structure and processes in the PROs will leverage their capacity to be more efficient and competitive. Recognize and value the role and responsibilities of the research administrator in research institutions will permit to make the best use of resources, including the human resources since researchers could focus in scientific activities and let the RMA professionals deal with more skill of the regulatory, administrative and bureaucratic activities, which should result in more agility and productivity.

The studies about strategic planning conducted by C. Matus since his graduation in 50s, with more force after his exile in 70s, built a significant framework of concepts and techniques to support the improvement of the management capacity of the government (MATTOS, 2010) $\square$. One of the concepts is the theory of the social game, the comprehension that a social actor belongs to a reality where there are variables that are controlled and others not controlled by him according to the current situation. The social game is unpredictable and the results are relative to the cognitive knowledge of the actor and his current situation in the reality. To the Chilean author, deal with the uncertainties during the planning development requires the adoption of complementary techniques, such as future studies (e.g. scenarios), vulnerability and reliability analysis, a monitoring system, and ex ante and ex post evaluation of operations (MATUS, 1991) $\square$.

The SSP methodology enabled a deep analysis of the macro problem proposed and a look through in several partial problems that affect it according to the R\&D Manager perspective. It is important to have in mind that the problem can be also a threat or an opportunity for other actors from a different perspective. According to Matus (1996), the causes can be controlled or influenced by the actors according to the rules, accumulations (capacities) and movements in the game. The influence is a shared control and can be strong, medium, weak or null. The selected critical nodes made explicit the causes in which the R\&D Manager has control, but it is strategic to notice that all the identified CCs are areas of influence of the actor. If the PROs are aware of their strategy and priorities, and adequately prepared and familiarized with the ST\&I policies and regulations, they will have more power of influence to collaborate 
in further developments and adjustments of these issues to have their specificities properly considered.

Mattos (2010) $\square$ reinforces the differences of the traditional planning and strategic planning proposed by Matus (1996) $\square$, remembering the importance of the planning taking into account what is necessary and what is possible. It is important the social actor know not only what their community or institution wants, but what are the possibilities according to their capabilities to achieve these goals in the current context and involved actors. The SSP methodology supported this study in the discovery of the actors and social game in place, contributing that a decision maker in a PRO be conducted not only to identify the variables he has already control and can act about, but also what are other arenas where he and his team could be more participative or not, thinking beyond the ordinary and obvious strategy, to gain more control and influence (MATUS, 1991) $\square$. Even that C. Matus studies were developed several years ago, his view about the importance of the government capabilities development and improvement aligned to the regional specificities and that the design and management tools are as significant as the content of the government project, are very aligned with recent discussions about the relevance of the adequated processes and tools to the conception, follow up, monitoring and evaluation of ST\&I public policies (EDQUIST, 2015; PACHECO; BONACELLI; FOSS, 2017; ARBIX, 2019).

\section{CONCLUSION}

The study reports the analysis of the causes and consequences of the reduced efficiency of Brazilian PRO regarding in applying their financial, physical and human resources in R\&D projects. The work was conducted in the R\&D Manager perspective, using SSP approach. The problem and its analysis, although complex, provided some understanding of the social relations involved, the importance of the governability of the actor to have control or influence on it, and the work fronts where he could act.

The application of SSP methodology and the design of the situational flowchart gave us a very detailed overview of the macro problem, including its descriptors, consequences and several causes that impact the R\&D projects and their efficiency in the use of resources. Literature review was promoted to base the analysis of the 42 causes identified and organized in six CCs which permeate the following topics: ST\&I public policies, legislation and 
regulations, innovation and collaborations, research administration and management capacity and structure, and contingency of resources for ST\&I.

The findings also pointed that when reviewing and redirecting their strategy, PROs must take into account the implementation of RMA structure and processes. Build capacity in RMA is a relevant path to the PRO management team has more influence in the ST\&I policy arena, aiming demand-side policies that simplify processes and align laws and regulations in order to stimulate collaborations and private funding.

Future studies in the area related to the internal environment of Brazilian PROs could understand how RMA processes are organized in these institutions, the existent gaps, and improvement areas. The recognition of RMA profession in operational level in less developed countries like Brazil is also a topic of study. Regarding the external environment would be very interesting to explore the influences network in the development of ST\&I public policies and how to increase PRO management and administrative team participation and empowerment on it, and therefore, validate the importance of RMA capability in such task.

\section{REFERENCES}

ALBUQUERQUE, M. E. E.; BONACELLI, M. B. M. A construção de rotinas e capacidades organizacionais para a viabilização de novas trajetórias nos institutos e centros de $\mathrm{P} \& \mathrm{D}$ brasileiros. In: MONTEIRO, M.; CAMPOS, C. De; DIAS, R. de B. (Eds.). Novos Horizontes em Política Científica e Tecnológica. Santo André: Universidade Federal do ABC, 2014. p. $15-36$.

ANDERSEN, J. Preaward-Project Preparation. In: ANDERSEN, J. et al. (Eds.). Research Management: Europe and Beyond. London: Elsevier Inc., 2017. p. 147-171.

ANGELO, C. Scientists plead with Brazilian government to restore funding. Nature News, v. 550, n. 7675, p. 166-167, 2017. Disponível em:

http://www.nature.com/doifinder/10.1038/nature.2017.22757 Acesso em: 15 nov. 2018.

ARBIX, G. et al. Avanços, Equívocos e Instabilidade das Políticas de Inovação no Brasil. NovosEstudos, n. 109, p. 8-27, 2017.

ARBIX, G. Innovation policy in Brazil since 2003: advances, incoherencies, and discontinuities. In: REYNOLDS, E. B.; SCHNEIDE, B. R.; ZYLBERBERG, E. (Eds.). Innovation in Brazil: Advancing Development in the 21st Century. Abingdon: Routledge, 2019.

AZEVEDO, C. da S. Planejamento e gerência no enfoque estratégico-situacional de Carlos Matus. Cadernos de Saúde Pública, v. 8, n. 2, p. 129-133, 1992. 
BARBOSA, A. S. Implicações éticas do efeito Mateus na ciência. Mediações - Revista de Ciências Sociais, v. 21, n. 1, p. 286, 2017.

BASTOS, M. I.; COOPER, C.The politics of technology in Latin America.London and New York: Routledge, 1995.

BASTOS, V. D. Fundos Públicos para Ciência e Tecnologia. Revista do BNDES, v. 10, n. 20, p. 229-260, 2003.

BIN, A.; SALLES-FILHO, S. Science, Technology and Innovation Management: Specificities and Conceptual Premises. International Joseph A. Schumpeter Society Conference-the southern conference, n. i, p. 1-25, 2008.

BONACELLI, M. B. M. Inovação no Brasil - A hora de uma verdadeira interação entre competitividade e CT\&I - Inova. Inova Unicamp, 7oct. 2013. Disponível em: https://www.inova.unicamp.br/noticia/2600/Acessoem: 15 nov. 2018.

BORRÁS, S.; EDQUIST, C. Institutions and Regulations in Innovation Systems: Effects, Problems and Innovation Policy Design. Papers in Innovation Studies, n. 20, 2014.Disponível em: http://www.circle.lu.se/upload/CIRCLE/workingpapers/201429_Borras_Edquist.pdfAcesso em: 29 jun. 2019.

BRAMA.Brazilian Research Administration and Management Association Press Release.São Paulo: BRAMA, 2018.

BUAINAIN, A. M. A crise e o futuro da Embrapa | Unicamp. 2018. Disponível em: https://www.unicamp.br/unicamp/ju/artigos/antonio-marcio-buainain/crise-e-o-futuro-daembrapa Acesso em: 15 nov. 2018.

CARVALHO, F. P. De. Cooperação e alianças para a inovação e o desempenho das empresas brasileiras. In: SERGIO SALERNO, M. et al. (Eds.). Inovação: Estudo de jovens pesquisadores brasileiros. 1a. Edição ed. São Paulo: Editora Papagaio, 2010. p. 465-484.

CGEE. Modelos institucionais das organizações de pesquisa. Brasília: Centro de Gestão e Estudos Estratégicos (CGEE), 2010. Disponível em:

https://www.cgee.org.br/documents/10182/734063/3_2010_modelos_institucionais_3_9555.p dfAcesso em: 22 sep. 2018.

CHESBROUGH, H. Open Innovation: A New Paradigm for Understanding Industrial Innovation. In: CHESBROUGH, H.; VANHARVEBEKE, W.; WEST, J. (Eds.). Open Innovation Researching a New Paradigm. New York: Oxford University Press, 2006. p. 112. 
CHRISTENSEN, J. F. Wither Core Competency for the Large Corporation in an Open Innovation. In: CHESBROUGH, H.; VANHARVEBEKE, W.; WEST, J. (Eds.). Open Innovation: Researching a New Paradigm. New York: Oxford University Press, 2006.

CONFIES; MCTIC; SEBRAE. O que pensa o pesquisador brasileiro sobre a burocracia?, 2017. Disponível em:http://confies.org.br/institucional/wpcontent/uploads/2017/03/pesquisa_o_que_pensa_o_pesquisador.pdf Acesso em: 1 jul. 2019.

CRESTANA, S.; MORI, C. De. Tecnologia e inovação no agro: algumas tendências, premências e drivers de mudanças. In: Propriedade Intelectual e Inovação na Agricultura. Brasília, DF: INCT/PPED, 2015. p. 59-88.

CUNNINGHAM, J. et al. The inhibiting factors that principal investigators experience in leading publicly funded research. Journalof Technology Transfer, v. 39, n. 1, p. 93-110, 2014.

DE NEGRI, F. Inovação e Produtividade: Por Uma Renovada Agenda de Políticas Públicas. Radar, v. 42, p. 7-15, 2015.

DE NEGRI, F. et al. Inovação no brasil: crescimento marginal no período recente. Brasília: IPEA, 2016. Disponível em: http://www.ipea.gov.br/portal/images/stories/PDFs/nota_tecnica/20161209_nt_34.pdfAcesso em: 22 sep. 2018.

DE NEGRI, F. Ciência e tecnologia no Brasil, desafios inadiáveis - Opinião - Estadão. O Estado de S. Paulo, 3 nov. 2016. Disponível em: https://opiniao.estadao.com.br/noticias/geral,ciencia-e-tecnologia-no-brasil-desafiosinadiaveis,10000086083Acessoem: 15 nov. 2018.

EDLER, J.; GEORGHIOU, L. Public procurement and innovation-resurrecting the demand side.Research Policy, v. 36, p. 949-963, 2007.

EDQUIST, C. Innovation-related Public Procurement as a Demand-oriented Innovation Policy Instrument.CIRCLE Lund University, 2015.Lund, v. August 201, n. 28, 2015, 2015.

ESCOBAR, H. Brazilian scientists lament "freeze" on research budget. Science (New York, N.Y.), v. 364, n. 6436, p. 111, 2019.

FAPESP. Escritório de Apoio Institucional ao Pesquisador (EAIP). 2018a. Disponível em: http://www.fapesp.br/eaip Acesso em: 22 sep. 2018.

FAPESP. Relatório de Atividades FAPESP 2017, FAPESP, 2018b. Disponível em: http://www.fapesp.br/relatorios_2017/RA2017.pdf Acesso em: 15 nov. 2018. 
FIGUEIREDO FILHO, W. B.; MÜLLER, G. PLANEJAMENTO ESTRATÉGICO

SEGUNDO MATUS : PROPOSTA E CRÍTICA. In: GERARDI, L. H. de O.; MENDES, I. A. (Eds.). Do natural, do social e suas interações: visões geográficas. Rio Claro-SP: Programa de Pós-Graduação em Geografia - UNESP, 2002. p. 121-132.

FORTIS, M. F. de A. Rumo à Pós-Modernidade Em Políticas Públicas: a Epistemologia Situacional De Carlos Matus. RAE-eletrônica, v. 55, n. 11, p. 26, 2010.

FRISCHTAK, C. R. Science and Technology in Brazil: where to now? In: REYNOLDS, E. B.; SCHNEIDE, B. R.; ZYLBERBERG, E. (Eds.). Innovation in Brazil: Advancing Development in the 21st Century. Abingdon: Routlege, 2019.

GAZETA DO POVO. Bloqueios no orçamento por ministério, Gazeta do Povo, 2019. Disponível em: https://infograficos.gazetadopovo.com.br/politica/bloqueios-no-orcamentopor-ministerio/Acesso em: 29 jun. 2019.

GIBBONS, M. et al.The new production of knowledge: the dynamics of science and research in contemporary societies. London: SAGE Publications, 1994.

HAGEDOORN, J. Inter-firm R\&D partnerships: an overview of major trends and patterns since 1960. ResearchPolicy, v. 31, n. 4, p. 477-492, 2002.

IBGE. Pesquisa de Inovação 2014 (Pintec). Rio de Janeiro: Instituto Brasileiro de Geografia e Estatística (IBGE), 2016. Disponível em: http://www.pintec.ibge.gov.br/downloads/PUBLICACAO/PUBLICAÇÃO PINTEC 2014.pdfAcesso em: 22 sep. 2018.

IIDA, I. Planejamento Estratégico Situacional. Produção, v. 3, n. 2, p. 113-125, 1993. JORNAL DA CIÊNCIA. Carta contra corte de 42,27\% no orçamento do MCTIC recebe apoio de sociedades científicas - Jornal da Ciência. 2019. Disponível em:

http://www.jornaldaciencia.org.br/carta-contra-corte-de-4227-no-orcamento-do-mctic-recebeapoio-de-sociedades-cientificas/Acesso em: 29 jun. 2019.

KERRIDGE, S. R. Electronic Research Administration Reflections on Research Management and Administration (RMA) in UK universities and in particular on Electronic Research Administration (ERA) and its perceived effect on the quality and quantity of research. 2012. University of Sunderland, Sunderland, 2012. Disponível em: https://sure.sunderland.ac.uk/id/eprint/3290/Acesso em: 29 jun. 2019.

KERRIDGE, S.; SCOTT, S. Research Administration around the world.Research Management Review, v. 23, n. 1, p. 1-34, 2018.

LANGLEY, D.; OFOSU, M. H. Celebrating a profession: the global perspective. JournalofResearchAdministration, v. 38, p. 39-43, 2007. 
MARQUES, F. Os impactos do investimento. Revista Pesquisa FAPESP, v. 246, p. 16-23, 2016.

MARQUES, F. Funding in crisis.Revista Pesquisa Fapesp, São Paulo, p. 20-29, 2017. Disponível em: http://revistapesquisa.fapesp.br/en/2017/12/10/funding-in-crisis/Acesso em: 29 jun. 2019.

MATTOS, R. A. (Re)visitando alguns elementos do enfoque situacional: Um exame crítico de algumas das contribuições de Carlos Matus. Ciencia e Saude Coletiva, v. 15, n. 5, p. 2327-2336, 2010.

MATUS, C. O plano como aposta. São Paulo em perspectiva, v. 5, n. 4, p. 28-42, 1991.MATUS, C. Política, Planejamento e Governo. Brasília: IPEA, 1993.

MATUS, C. Método PES: Roteiro de Análise Teórica. Campinas, SP: FUNDAP, 1996.

MERTON, R. K. The Matthew Effect in Science: The reward and communication systems of science are considered. Science, v. 159, n. 3810, p. 56-63, 1968.

MIRANDA, A. L. B. B. et al. Inovação nas universidades: uma análise do novo marco legal. Revista ENIAC Pesquisa, v. 8, n. 2, p. 85-98, 2019.

MONTEIRO, V. Burocracia consome mais de $30 \%$ do tempo dos cientistas, constata pesquisa. Jornal da Ciência, 27 jan. 2017. Disponível em:

http://www.jornaldaciencia.org.br/burocracia-consome-mais-de-30-do-tempo-dos-cientistasconstata-pesquisa/ Acesso em: 29 jun. 2019.

MYERS, P. E. Celebrating the First Forty Years of the Society of Research Administrators International. The Journal of Research Administration, v. XXXVIII, p. 19-30, 2007.

ODELIUS, C. C.; ONO, R. N. Características da colaboração científica entre grupos de pesquisa de áreas de exatas, vida e humanas. Cadernos EBAPE.BR, v. 17, n. 1, p. 101-116, 2019. Disponível em: http://dx.doi.org/10.1590/1679-395164739Acesso em: 3 may. 2019.

OECD.OECD Science, Technology and Innovation Outlook 2016, OECD Publishing, 2016.Disponível em: http://www.oecd-ilibrary.org/science-and-technology/oecd-sciencetechnology-and-innovation-outlook-2016_sti_in_outlook-2016-en Acesso em: 30 aug. 2018.

OLIVEIRA, F. S. De et al. Dinâmica da formação de redes de PD\&I: a experiência da Embrapa Informática Agropecuária na articulação de Parcerias Público-Privadas (PPP). In: VI SINGEP 2017, São Paulo-SP, Brazil. Anais... São Paulo-SP, Brazil 
PACHECO, C. A.; BONACELLI, M. B. M.; FOSS, M. C. Políticas de estímulo à demanda por inovação e o Marco Legal de CT\&I. In: COUTINHO, D. R.; FOSS, M. C.; MOUALLEM, P. S. B. (Eds.). Inovação no Brasil: avanços e desafios jurídicos e institucionais. São Paulo: Blucher Open Access, 2017. p. 213-240.

PARANHOS, J.; CATALDO, B.; PINTO, A. C. de A. Criação, Institucionalização e Funcionamento dos Núcleos de Inovação Tecnológica no Brasil: Características e Desafios. Revista Eletrônica de Administração, v. 24, n. 2, p. 253-280, 2018.

PENTEADO, M. I. et al. A trajetória do planejamento da pesquisa na Embrapa. Cadernos de Ciência \&Tecnologia, v. 31, n. 1, p. 35-60, 2014.

PIRES, J. C. de S.; MACÊDO, K. B. Cultura Organizacional nas Organizações Públicas no Brasil. Revista de AdministraçãoPública, v. 40, n. 1, p. 81-104, 2006.

POLI, S. Who Are Today's Research Managers? In: ANDERSEN, J. et al. (Eds.). Research Management: Europe and Beyond. London: Elsevier Academic Press, 2018. p. 2-29.

RACC.Certified Research Administration Body of Knowledge (CRABoK).2018.

Disponível em: http://www.cra-cert.org/cra-body-of-knowledge/ Acesso em: 26 sep. 2018.

RIBEIRO, V. C. dos S.; SALLES-FILHO, S. L. M.; BIN, A. Gestão de institutos públicos de pesquisa no Brasil: limites do modelo jurídico. Revista de Administração Pública, v. 49, n. 3, p. 595-614, 2015.

SALLES-FILHO, S.; BONACELLI, M. B. M. Science and Public Policy Trends in the organization of public research organizations: lessons from the Brazilian case. Science and Public Policy, v. 37, n. 3, p. 193-204, 2010.

SALLES-FILHO, S.; PEDRO, E.; MENDES, P. J. V. Concepts, Policy Elements, and Regional Strategies for the Development of Institutional Innovation.San José, C.R.: IICA, 2007.

SBPC et al. Carta de manifestação pública: sobre cortes do orçamento, que atingirão em cheio a CT\&I nacional, SBPC, 2019. Disponível em: http://sbpcacervodigital.org.br/handle/20.500.11832/4952 Acesso em: 29 jun. 2019.

SJR.SJR - International Science Ranking.2018. Disponível em: https://www.scimagojr.com/countryrank.phpAcesso em: 26 sep. 2018.

TOOM, K. Indicators. In: ANDERSEN, J. et al. (Eds.). Research Management: Europe and Beyond. London: Elsevier Inc., 2017. p. 213-230.

UNESCO. Relatório de ciência da UNESCO: Rumo a 2030 - Visão Geral e Cenário Brasileiro. Paris: UNESCO, 2015. 
USPTO.Patent Counts By Country, State, and Year - All Patent Types (December 2015). 2015. Disponível em: https://www.uspto.gov/web/offices/ac/ido/oeip/taf/cst_all.htm Acesso em: 15 nov. 2018.

VERDE, L. H. L.; MIRANDA, J. I. de R. Uma análise econômica dos resultados brasileiros no Índice Global de Eficiência em Inovação, frente ao novo Marco da Ciência, Tecnologia e Inovação (Lei n. 13.243/2016). Economic Analysis of Law Review, v. 9, n. 2, p. 308-337, 2018. 